\title{
A IDEOLOGIA SIONISTA E O RENASCIMENTO DA LÍNGUA HEBRAICA EM MISSAVIV LANEKUDÁ DE YOSSEF HAIM BRENNER
}

\author{
Gabriel Steinberg*
}

\section{Resumo}

Yossef Haim Brenner nasceu em 1881 no então Império Russo e morreu na Terra de Israel em 1921 aos 40 anos. É considerado pioneiro da nova literatura hebraica, além de pensador e líder público. Em seus contos mais importantes, Brenner aborda a questão da transição linguística do iídiche para o Hebraico, uma das expressões máximas da empreitada sionista na terra ancestral. Em 1904 Brenner saiu da Rússia e se estabeleceu na Inglaterra. No mesmo ano publicou o conto Missaviv Lanekudá (Em torno do ponto) no periódico Hebraico Hashiloach, cujo editor na época era Chaim Nacham Bialik, figura central da moderna literatura hebraica. Em 1909 imigrou para a então Palestina, onde passou a dedicar-se à literatura de profundo cunho ideológico. Esta comunicação apresentará um relato da obra de Brenner no período da renovação da língua hebraica nos primórdios da colonização judaica na Terra de Israel.

Palavras-chave: literatura hebraica, língua hebraica, sionismo, diáspora, renascimento da língua hebraica

\section{Abstract}

Yosef Haim Brenner was born in 1881 in what was the Russian Empire and died in the Land of Israel in 1921 at the age of 40. He is considered a pioneer of the New Hebrew literature, and a public thinker and leader. In his most important short story, Brenner addresses the linguistic transition from the Yiddish

\footnotetext{
* Professor Doutor de Língua Hebraica do Departamento de Letras Orientais da Faculdade de Filosofia, Letras e Ciências Humanas da Universidade de São Paulo. <steinberg1818@ hotmail. com>
} 
language to Hebrew, one of the highest expressions of the Zionist enterprise in ancestral land. In 1904 Brenner left Russia and settled in England. In the same year he published the short story Misaviv Lanekuda (Around the point) in the Hebrew journal Hashiloach, whose editor at the time was Chaim Nacham Bialik, the central figure of Modern Hebrew literature. In 1909 he immigrated to Palestine where he devoted himself to literature of deep ideological. Content this communication will present an account of the work of Brenner during the renovation of the Hebrew Language at the beginning of Jewish settlement in the Land of Israel.

Keywords: Hebrew literature, Hebrew language, Zionism, Diaspora, revival of the Hebrew language

$\mathbf{N}^{2}$ a segunda metade do século XIX, com o auge dos movimentos nacionalistas na Europa Central e Ocidental, e devido à escalada das perseguições antissemitas, aumentou o número de judeus que aderiram a estas correntes e passaram a adotar as línguas faladas e escritas em seus países de residência. O despertar político e cultural que os povos europeus vivenciavam incluía o renascimento de suas línguas populares além da elevação da língua à função da cultura, ampliando-a para atender às necessidades linguísticas da modernidade. Os judeus inseridos nestes embates nacionalistas na Europa também tiveram que criar um movimento que lhes permitisse adentrar como iguais à cultura europeia. No final do século XVIII tinha surgido na Europa Central o movimento do Iluminismo judaico chamado Hascalál ${ }^{1}$, que pretendia normalizar a vida do judeu, inserindo-o no mundo da cultura europeia secular e moderna.

Do ponto de vista histórico, o papel da Hascalá foi vital para o renascimento da Língua Hebraica e do "novo homem hebreu". Este movimento preparou os fundamentos para o uso do Hebraico na vida do dia a dia ao dar vida ao Hebraico literário. Para os movimentos nacionalistas do século XIX na Europa, a prova mais decisiva para a existência de um povo e das fronteiras nacionais que se desejava traçar, era o uso da língua como símbolo de união e de reconhecimento identitário como grupo. Com os judeus não foi diferente e, como afirma Barrocas:

1 Hascalá - Designa o movimento da Ilustração judaica iniciado na Alemanha na segunda metade do século XVIII tendo como figura principal o filósofo Moses Mendelsshon. 
Quanto ao lugar da Língua Hebraica no processo do renascimento nacional judaico, a fala do Hebraico servia de alavanca para 0 renascer nacional-político, ideia característica da Europa do final do século XIX. (BARROCAS, 2006, p. 45)

Os maskilim, integrantes do movimento da Hascalá, que pretendiam introduzir o judeu na cultura europeia, foram também os responsáveis pela renovação da língua Hebraica escrita ao valorizarem o estrato bíblico inicial em detrimento do Hebraico mishnaico (a língua dos sábios) e do Hebraico medieval usado até então na literatura. Distantes das aspirações nacionalistas, este esforço feito pelos homens ilustrados possibilitou mais tarde o renascimento da língua falada já em solo da Palestina no final do século XIX. Neste contexto teve um papel preponderante Eliezer Ben Yehuda, linguista e jornalista que chegou à Terra de Israel em 1881, no início da primeira onda imigratória, quando ficou claro o fracasso do movimento iniciado um século antes com o surgimento da Hascalá, devido ao recrudescimento do antissemitismo amplamente disseminado pela Europa.

O renascimento da língua falada foi antecedido por um despertar de intelectuais judeus que na Europa deram continuidade ao movimento da Hascalá e decepcionados com o processo de emancipação político e social, aderiram ao nacionalismo judaico que pretendia recriar uma entidade autônoma, um estado judaico próprio na terra ancestral. Na Europa da segunda metade do século XIX, vários escritores e intelectuais começaram a escrever obras literárias, poesia e prosa e a publicar seus escritos em jornais e suplementos literários exclusivamente em Hebraico. Vale lembrar que tais jornais tinham uma circulação muito restrita devido ao número extremamente reduzido de pessoas capazes então de ler literatura não religiosa. Neste contexto de efervescência cultural e política se encontrava entre outros, Yossef Haim Brenner.

Brenner nasceu em 1881 numa pequena aldeia, um schtetl, chamado Novia Mlini no então Império Russo, e morreu assassinado durante um distúrbio Árabe contra a população judaica na Palestina Britânica em 1921, aos 40 anos. É considerado pioneiro da nova literatura hebraica, além de pensador e líder 
público. Sua morte trágica o transformou numa figura quase mítica no período em que ocorria em Israel o renascimento do Hebraico como língua nacional. Em seus contos mais importantes, Brenner aborda a questão da transição linguística pela qual os judeus na diáspora e os pioneiros na terra de Israel passavam de forma concomitante, movidos pelos ideais nacionalistas, do í́diche, uma língua judaica considerada inferior por ser diaspórica, para o Hebraico, uma das expressões máximas da empreitada sionista na terra ancestral.

Brenner começou sua educação em escolas rabínicas, porém tornou-se em sua juventude um opositor ferrenho do movimento hassídico. ${ }^{2}$ Em 1896, quando tinha 15 anos, foi expulso da escola rabínica ao ser pego lendo literatura considerada profana pois era escrita em Hebraico. Este fato teve forte influência em sua obra até o final de sua vida. Desde então procurou conhecer a cultura judaica de cunho não religioso e a cultura europeia, em especial a russa. Em 1898 vivendo em Byalistok (atual Polônia) procurou sobreviver como escritor e filiou-se ao movimento socialista e ao partido Bund. ${ }^{3}$

Brenner publicou seu primeiro conto em Hebraico chamado Pat Lechem (Uma fatia de pão) no ano de 1900 quando ainda morava na Rússia no periódico Hamelitz. ${ }^{4}$ Em 1904, por ocasião da Guerra Rússia - Japão fugiu se estabelecendo na Inglaterra. Ali se afastou do Bund e se aproximou dos escritores e intelectuais em língua hebraica. Em Londres também participou da edição do suplemento literário Hameorer $^{5}$ e filiou-se ao partido sionista socialista Poalei Sion. Também em Londres publicou em 1904 o livro romance Missaviv Lanekudá (Em torno do ponto)

2 Hassidismo: Corrente religiosa judaica nascida em meados do século XVIII na Europa Oriental, como uma iniciativa do rabino Baal Shem Tov. Este movimento visava a promover a face mística da espiritualidade judaica, disseminando entre os judeus mais humildes a mística piedosa como um elemento essencial de sua fé.

3 Bund: Movimento político operário judeu socialista, surgido no Império Russo em 1897 e que se opunha ao sionismo, mas também à tendência centralizadora dos movimentos bolcheviques em forte agitação nesse então no país.

4 Hamelitz (O Conselheiro) - foi um periódico hebraico publicado na Rússia entre 1860 e 1904. Neste jornal escreveram também Achad Haam e I.L.Gordon.

5 Hameorer - Suplemento literário em língua hebraica editado em Londres entre os anos de 1906- 1907. Brenner foi um de seus editores. Neste suplemento aparecerem publicados textos literários dos mais destacados escritores hebraicos da época como: Dvora Baron, Guershon Schofman, Yaacov Fichman, Micha Yossef Berdichevsky, assim como a tradução para o hebraico de obras da literatura inglesa. 
no periódico Hebraico Hashiloach ${ }^{6}$ de Odessa (atual Ucrânia), cujo editor na época era Chaim Nacham Bialik, figura central da moderna literatura e poesia hebraicas. Em 1909 imigrou para a Palestina passando a dedicar-se ao trabalho como agricultor, convicto que o renascimento do povo em sua terra ancestral somente ocorreria se os judeus voltassem a exercer trabalhos manuais e agrícolas. Não resistindo à árdua carga, abandonou o trabalho na terra e passou a dedicar-se à literatura de profundo cunho ideológico. Foi ser professor no Ginásio Herzlia em Tel Aviv onde lecionava Literatura, Gramática, Tanach e Mishná. Em 1911 publicou outro livro de relevante importância para o renascimento do Hebraico chamado Mikan Umikan (Daqui e daqui). Traduziu para o Hebraico obras dos grandes escritores russos da época como Crime e Castigo de Dostoiévski e obras literárias de Tolstói.

Brenner foi um dos primeiros escritores de sua geração a expressar a crise nacional e social do indivíduo judeu angustiado diante do mundo hostil e estranho que o rodeia e que não o aceita, onde o herói de sua narrativa enfrenta uma crise existencial, doenças do corpo e da alma, e peregrina de lugar em lugar a procura de um objetivo que lhe devolva alguma paz. O herói de Brenner vive um forte conflito interno, pois se encontra enclausurado na Área de Residência, território no qual os judeus do Império Russo foram confinados, pelas leis de 1795 e 1835. Esta política discriminatória tinha por objetivo separar os judeus da população russa impedindo-os de prosperar economicamente, de exercer profissões liberais, de ingressar nas universidades, e instigando-os a partir da Rússia. Em 1885 havia mais de quatro milhões de judeus vivendo na área do Pale. Segundo as Leis de Maio de 1882 promulgadas pelo Czar Alexander III, os judeus não tinham permissão para transferir moradia para qualquer ponto desta área rural do Pale, muito menos habitar em cidades fora desta área.

O conflito interno do herói dos contos de Brenner vive esta angústia de estar confinado, de ser discriminado pelas autoridades, de se sentir um bode expiatório da tensão social e política pela qual atravessava o Império Russo da passagem do século XIX para o seguinte. O personagem de Brenner vive na pequena aldeia do Leste da Europa, onde não consegue aguentar o clima de encerramento espiritual e religioso que o oprime e, por essa razão, foge para a cidade grande. No entanto,

6 Hashiloach - Periódico mensal em língua hebraica criado por Achad Haam em Odessa em 1896, cuja linha editorial se opunha com veemência à língua iídiche considerada um jargão. Em 1920 passou a ser editado em Jerusalém até que parou de circular em 1927. 
percebe que esta saída foi apenas um subterfúgio e que o gueto que o judeu carrega em sua alma oprimida o persegue em todos os lugares. Mesmo quando ele abandona o pequeno schtetl e chega às grandes cidades da Rússia, eles se sente oprimido, a Área de Residência o aprisiona física e espiritualmente.

Brenner pertence a uma geração de escritores que nasceu no Leste da Europa e dali peregrinou pelo mundo judaico até chegar à Terra de Israel. A visão de mundo destes escritores como Gansin e Schofman, se move entre dois extremos: a decepção constante e a esperança num futuro melhor. Os escritores desta geração se decepcionaram diante da pobreza cultural de seu povo ocupado apenas com a sobrevivência econômica, numa época de desesperança motivada também pelo avanço do antissemitismo na Europa Central e Oriental, e pelo aumento da perseguição legal e institucional das autoridades do Império Russo, que por sua vez estava chegando a um período de profunda ruptura e que se valia dos judeus como um depositário dos males que o afligiam. Os escritores de língua hebraica contemporâneos de Brenner pareciam encontrar-se diante de uma cultura em ruínas, sem leitores para suas obras, num período de carência econômica e cultural. Ao contrário de Bialik e Klausner, que sustentavam que a escrita dos jovens da época sinalizava para o renascimento da literatura hebraica (BIALIK, 1972); Brenner afirmava que sua literatura mostrava uma realidade de decadência e de desmoronamento (SHAKED, 1977, p. 361). Brenner ainda via com descrença a possibilidade do acordar da língua. Mesmo assim, ele abandonou a Europa e em 1909 se engajou na empreitada sionista na Palestina.

Brenner foi o primeiro de sua geração a quebrar os padrões quanto ao estilo linguístico e literário da língua utilizada no início do século. Em suas obras há uma mistura do Hebraico com o Árabe, o Iídiche e o Russo, fato que se tornou depois corriqueiro aos escritores que chegaram à Terra de Israel durante a segunda aliá$^{7}{ }^{7}$ esta que mudaria de forma profunda a estrutura econômica, social 
e ideológica do pequeno assentamento judaico existente então na Palestina. Para Brenner era legítimo abrir caminho na língua hebraica que estava em processo de renascimento para a influência europeia, fato este que contribuiria para "elevar" e aproximar o Hebraico das chamadas "línguas vivas". Foi duramente criticado pelos círculos religiosos judaicos que viram nele um perigoso dissidente, ao relatar na literatura personagens que se sublevavam contra o mundo tradicional judaico e contra a imposição ortodoxa rígida que, segundo Brenner, mantinha o judeu à margem da cultura europeia vista pelo seu avanço e progresso como uma ameaça à cultura tradicional judaica (SHAKED, 1977, p. 365).

Como crítico tanto na Europa onde editou os suplementos literários Hameorer (Londres, 1906-1907) e Revivim (Lvov, 1908-1909), como em Israel onde editou o suplemento Haadamá (Yafo, 1919-1921), Brenner se sublevou contra o passado diaspórico judaico, ao qual ele não creditava qualquer importância. Para ele a existência judaica na diáspora tornou os judeus num povo parasitário, pois tirou dele qualquer capacidade produtiva, e foi um período de profundo sofrimento histórico. Somente a vida produtiva poderia salvar o povo da miséria física e intelectual na qual se encontrava espalhado pela dispersão. Ele chegou a questionar dizendo:

O que devemos fazer nós os judeus? Como deveríamos viver? Como deixar de ser um povo parasita em todos os sentidos? Como devemos adquirir condições de criação produtivas? Como deixar de ser os filhos do gueto? (SHAKED, 1977, p. 367)

Anita Shapira, biógrafa de Brenner, afirma que tendo chegado a Israel à época da $2^{a}$ aliá, em 1909, Brenner faz parte de um grupo que se tornou preponderante na formação do etos sionista socialista, em especial na formação do etos colonizador como um componente central e dominante da cultura do Ishuv ${ }^{8}$ na Terra de Israel. A maior parte dos que chegaram nesta onda imigratória provinham da Área de Residência e o apego que sentiam às

8 Ishuv-(Lit: "comunidade, coletividade") refere-se à comunidade judaica estabelecida na Palestina no período anterior ao estabelecimento do Estado de Israel. 
ideias assimiladas do arsenal revolucionário russo era inquestionável. Brenner faz parte do grupo de idealistas que tudo sacrificavam, até a própria vida, em prol da nacionalidade que estava sendo reconstruída. Ele estava convicto que o homem devia não apenas acreditar na ideia da redenção nacional, senão que devia também viver segundo essa crença. Desta forma, Shapira sintetiza o pensamento de Brenner e afirma que:

Para ser um bom sionista não era suficiente acreditar na ideia sionista, era preciso ir para Eretz Israel e lá, na Terra de Israel, não era suficiente acreditar na importância do retorno do povo ao trabalho agrícola, era preciso criar um grupo de trabalhadores agrícolas hebreus que fossem semelhantes aos mujiques russos que trabalhassem a terra com suas próprias mãos, porque a terra somente pertence a quem nela trabalha. Estas ideias foram a tradução hebraica das ideias que rondavam o panorama da cultura russa da passagem do século XIX para o XX, o mundo no qual se inseria Brenner. (SHAPIRA, 2007, p. 209-210)

As andanças de Brenner pelo mundo judaico especialmente pelas principais cidades de grande presença judaica do Leste da Europa e mais especificamente, pelos centros do iluminismo cultural judaico são retratadas em seus contos e romances. Seus personagens fazem esse percurso à procura da redenção, de um novo sentido para uma vida marcada pela opressão externa e interna. Em sua obra ele mostra como poucos, um cotidiano de extremo realismo. Um fato determinante em sua obra é que muitos de seus heróis saem à procura de soluções para as angústias existenciais, porém, ao longo da trama eles acabam descobrindo que a fuga não os levou a lugar nenhum, que a redenção não pode ser alcançada, que o exílio está incrustado de forma profunda na alma de seu povo. A trama externa não soluciona os dilemas internos perante os quais o herói de Brenner se confronta.

Quando Brenner enviou à redação do jornal Hebraico Hashiloach, em 1904, o conto Missaviv Lanekudá (Em torno do ponto), Bialik, que era o editor 
do suplemento literário, apontou as qualidades do autor e o descreveu como um jovem ousado e inconformado com a época que lhe coube viver e com a diáspora judaica, vista por ele também como uma experiência doentia. Bialik viu em Brenner um jovem ávido por mudanças e por liberdade para seu povo e com ele compartilhava de uma visão negativa sobre a vida dos judeus fora de sua pátria ancestral e ao editar seu conto lhe escreveu o seguinte:

A relevância de sua obra apesar de conter influência européia, é basicamente a expressão da força criativa hebraica e fruto de um filho da diáspora, filho da Galut de nossos dias, que sua força de vontade e seu desejo são maiores do que sua capacidade de agir, que enxerga a decadência da nação e deseja sua libertação, e que acredita ao mesmo tempo em que duvida da possibilidade de conseguir essa liberdade, liberdade esta que ele não sabe onde se encontra e de onde ela virá. Mas isto ocorre, pois o surgimento de todo novo movimento e de toda ideia nova que atinge nosso povo, não surge de nós mesmos ou da terra, senão que vem para nós do ar. Nós captamos tudo do ar quando está tudo pronto e conclú́do e ainda, desfrutamos dos frutos dos outros sem vivenciar as dores do plantio, $\mathrm{e}$ da colheita. Território nós não temos e por isso, tudo a nossa volta é fictício e imaginário. Tudo na nossa vida na diáspora brilha e apodrece no mesmo dia. (BIALIK, 1972, p. 45-46)

O conto Missaviv Lanekudá foi escrito por Brenner em Londres, foi publicado em capítulos no suplemente literário do periódico Hebraico Hashiloach de Odessa (Ucrânia). O personagem principal do romance é Yaacov Abramson que abandonou sua aldeia natal a procura do mundo e chegou até a grande cidade denominada no romance com a letra Álef, provavelmente, letra inicial da cidade de Odessa, um dos centros do movimento iluminista judaico do 
Leste da Europa ${ }^{9}$. Ali Yaacov sofre, se apaixona, quer espalhar e popularizar o conhecimento da língua hebraica. Ele transita entre duas correntes que fervilhavam na época: o Sionismo e o Socialismo, no entanto, ele não se aproxima de nenhuma das duas ideologias, não se filia a esses movimentos, não acredita nas grandes crenças como sendo capazes de salvar o mundo judaico da opressão e miséria espiritual na qual se encontrava.

Yaacov sofre privações materiais, fome, falta de toda perspectiva, escreve artigos em Hebraico que tentará publicar nos poucos e inéditos jornais em língua hebraica que circulavam pelos mundo judaico, sabendo que seu público leitor é ao extremo limitado e até insignificante do ponto de vista numérico. Mesmo diante da tentação de escrever em russo, alcançando assim um grande público leitor podendo melhorar de vida livrando-se das privações constantes, ele não desiste. Ele resiste durante um bom tempo a escrever em Russo, a língua viva, a língua do poder, expressão da modernidade e da transformação. Ao contrário, ele teima em escrever na língua que denominava de Sfat Avar (a língua do passado) como se esta fosse um fóssil difícil de ser decifrado. Yaacov Abramson passa por inúmeras provas e mostra como é duro o processo de reviver a língua, numa sociedade na qual adquirir alimentos para a sobrevivência diária, era bem mais importante do que comprar jornais em Hebraico que era visto como um resquício do passado. Mais ainda, voltar a utilizá-lo na comunicação diária e na literatura era ainda encarado como uma grande utopia.

A narrativa se inicia na estação de trem, quando Yaacov Abramson se despede de seu aluno e discípulo Shlomo Frankel, e lhe diz que, assim como ele mesmo está partindo, a vida do aluno nesse lugar não tem mais valor, "você deverá partir daqui, existe uma outra vida renovada, um mundo de criação e de

Odessa - Cidade portuária ucraniana às margens do Mar Negro. No século XIX era a terceira cidade mais importante do Império Russo atrás apenas de Moscou e São Petersburgo. Os judeus se estabeleceram na cidade no século XIX quando esta se tornou um porto livre. Calcula-se que a população judaica somava mais de 160 mil pessoas no final do século, o que a tornou na maior cidade de população judaica do Império. Os judeus sofreram vários pogroms em 1881 e 1905. No final do século XIX se consolidou na cidade o movimento do iluminismo judaico, e muitos judeus passaram a frequentar escolas e universidades e também foi fundada ali uma escola judaica moderna. Nessa mesma época foi fundado um centro de apoio ao movimento sionista e Odessa se transformou numa importante base de atuação do movimento nacionalista judaico. Foi ali que atuaram os grandes escritores sionistas e pioneiros da moderna literatura hebraica como Bialik e Klausner. 
luz" (BRENNER, 1923, p. 1), uma clara referência à cidade grande que está distante dali mas que representa a passagem para o mundo ilustrado. Ao chegar à cidade A. Yaacov diz que: "ali era uma cidade onde a maioria dos moradores eram judeus e a maior parte dos que se encontravam naquele trem, também o eram" (BRENNER, 1923, p. 4). Ao chegar à cidade, ele se hospeda na casa de seu amigo Uriel Davidovsky. Esta era a casa de uma família simples onde o pai mantinha uma oficina de marcenaria. Abramson se mostra feliz e otimista no início da narrativa, ele conseguira fazer a transição do mundo tradicional e opressor judaico da aldeia para o mundo moderno, os sopros da ilustração chegaram às grandes cidades do Leste da Europa e agora Abramson, que saiu do gueto, está prestes a mudar por completo.

$\mathrm{Na}$ cidade A, Abramson passou a dedicar-se a escrever artigos que iria enviar aos periódicos em língua hebraica. Seu primeiro artigo o denominou "A influência do Movimento Hassídico do século XVIII sobre a literatura hebraica renovada do século XIX” (BRENNER, 1923, p. 15). A felicidade e otimismo de Abramson são encarados com suspeita por seu amigo Uriel Davidovsky que o encara como um ser utópico, como mais uma figura perdida na grande cidade e lhe diz: "você é um herege, um herege que não tem conserto" (BRENNER, 1923, p. 15), em alusão ao fato de alguém que ousa criticar o establishment judaico e ainda imagina que conseguirá mudar com seus escritos a realidade do mundo opressivo que o rodeia.

A chegada de Abramson à cidade começou a agitar os círculos sionistas, um deles era dirigido por Itzchak Ravkesh, o melamed (o professor). Itzchak Ravkesh é descrito no texto como

Um dos pássaros novos, um dos primeiros que chegaram à cidade $\mathrm{A}$. A grande cidade do sionismo e do iluminismo Hebraicos. Ele foi o primeiro que permitiu a entrada no seu cheder (a escola tradicional e de educação rígida e dogmática) de um pequeno armário com livros em Hebraico. Foi o primeiro também a fundar vários anos atrás um cheder renovado, com bancos compridos e livros de gramática e até livros com novos métodos de ensino. (BRENNER, 1923, p. 17) 
No entanto, o professor Itzchak Ravkesh sabia que ele estava preso a uma realidade, a um mundo tradicional onde os pais de seus alunos esperavam dele que incentivasse seus filhos a decorarem "aqueles versículos duros e estranhos" (BRENNER, 1923, p. 17), esperavam dele que os instruísse no caminho da tradição, essa tradição milenar que devia ser levada adiante de geração a geração. Mas a mente do melamed renovador não esmoreceu, ele sabia que podia ensinar a tradição de outra forma. No cheder renovado, os jovens se reuniam para ler algo inédito para a época: jornais do mundo além dos muros do cheder e mais ainda, jornais escritos em Hebraico. Mas a oposição contra a escola renovada, contra o cheder herético, crescia na mesma medida em que a procura por ele também crescia.

E então, apesar da oposição crescente, o professor Itzchak Ravkesh junto com seu conhecido e apoiador Haspanik, decidiram transformar o cheder renovado numa escola cujo lema passou a ser: "Ivrit beivrit", uma escola onde se ensinaria o Hebraico falado, as aulas seriam todas elas dadas em Hebraico, ali se ensinaria segundo o novo método: Hebraico em Hebraico. Este método segundo o professor Itzchak Ravkesh, era o método natural de ensino e desta forma a escola renovada se propunha a combater todos os velhos métodos e também, todos aqueles que ainda se dedicavam a ensinar às crianças no velho jargão, referindo-se é claro, ao Iídiche, visto como a língua da humilhação, a língua da decadência espiritual, símbolo da diáspora, a língua do judeu perseguido, em oposição ao Hebraico, símbolo da renovação.

Abramson chegou à grande cidade onde o ar fervilhava com os novos ventos do iluminismo judaico, com o sionismo e com o socialismo. Na casa do melamed Itzchak Ravkesh foi criada uma associação cultural denominada Bonei Tsion (os construtores de Sião). Ali se encontrava o armário com os livros "heréticos". Abramson saído da pequena aldeia opressiva judaica estava admirado com os ventos do iluminismo. Naquele verão, Abramson passou a frequentar a associação Bonei Tsion, porém ele não se associa, ao contrário dos outros, ele não consegue renegar a religião e a tradição, admira a nova realidade, mas não está pronto para quebrar a ligação com o passado tradicional. Para Abramson nacionalismo sem religião não tem sentido, o sionismo pecava a seus olhos por se apresentar como algo novo, como uma revolução que vinha suplantar a velha tradição judaica. Para ele, nacionalismo e religião eram 
fatores que se ligavam entre si fortemente, o nacionalismo que se propunha a suprimir a religião era um sacrilégio. Ele se posiciona e diz, mostrando-se dividido entre o mundo tradicional e os novos ventos: "Sem os princípios da religião não existe nacionalismo, o nacionalismo deve se sustentar apoiandose primeiro na religião. O shabat é um dos princípios do judaísmo, cuidar do shabat é um privilégio e deve ser um dos pilares do nacionalismo da nossa época". (BRENNER, 1923, p. 21)

Seu segundo artigo intitulado "A criação hebraica do início do século XX", entreteve Abramson por um longo tempo. Neste artigo, ele critica o destino reservado à língua hebraica e a parca literatura nesta língua que, segundo sua visão, encontrava-se numa situação de total agonia. Assim ele diz:

Como decaiu Sfat avar (a língua do passado), como se encontra em decadência nossa língua do passado, uma língua que não é falada, uma língua empobrecida. $O$ Povo do Livro, não compra mais livros, nossa literatura existe como que por um milagre, pobres são nossos escritores e pobre é a nossa literatura. (BRENNER, 1923, p. 29)

Mas ele, Abramson, é membro da geração do renascimento e no mesmo artigo que acabara de escrever ainda enxerga uma esperança num futuro melhor para a língua que tanto ama. Ele diz:

Renascimento. Feliz do homem hebreu que teve o privilégio de nascer nesta geração, a geração do renascimento. Somente agora há valor na vida do jovem hebreu, somente agora, na geração do renascimento nacional, na época em que o espírito hebreu original acorda e se renova, na hora em que o judaísmo começa a se libertar das amarras do passado e se enche de novos conteúdos. Agora o povo hebreu se aproxima dos outros povos. Como é feliz o novo jovem hebreu, seus olhos 
brilham e se iluminam diante da sagrada Torá. Livre, agora ele está livre de todo o exterior que o rodeia, desse exterior decadente, ele não mais precisa se subjugar a esse exterior. Agora, ele reponde somente ao Deus que estava oculto, o Deus que pode ser visto pelo homem, 0 Deus vivo. (BRENNER, 1923, p. 29)

No artigo que ele acabara de escrever, Abramson exalta a figura do novo hebreu que retorna aos ideais do período bíblico de liberdade e independência e até recria a língua desse passado glorioso. Ao escrever em Sfat avar (a língua do passado) Abramson se via como alguém que está participando da redenção de todo o povo de Israel. Ao se entregar por completo à escrita de seus artigos ele reflete sobre o grande momento que está vivenciando, assim diz a narrativa:

[...] ele via a si mesmo como um dos jovens pioneiros hebreus, como um dos israelenses do amanhã, um entre os que uma chama ardia em seus corações e eles serão os responsáveis por encontrar o caminho para a redenção. (BRENNER, 1923, p. 28)

\footnotetext{
Abramson se sente atraído pelos judeus ilustrados e compactua com seu discurso e sua ideologia. No entanto, ele ainda usa barba, ele encontra-se numa encruzilhada entre esses dois mundos. Sente-se atraído pela modernidade, mas está ligado ao mundo tradicional judaico cujos laços são difíceis de serem quebrados.

$\mathrm{Na}$ grande cidade, Abramson conheceu além dos sionistas outros jovens judeus, os que estavam ligados ao movimento socialista. Neste movimento havia jovens judeus que tinham adotado nomes russos como no caso de Hava Blumin pela qual Abramson se interessava e que adotou o nome de Yeva Issacovna. Abramson que segundo o relato estava na casa dos vinte anos, se encantou por Hava Blumin mas se ele estava interessado em casar com a moça
} 
da cidade grande, ela que fazia parte do grupo dos jovens judeus simpatizantes do socialismo, e também não enxerga no casamento qualquer utilidade. Casamento para Hava Blumin era coisa de burgueses, ali todos acreditavam no amor livre, sem amarras e sem formalidades.

$\mathrm{Na}$ narrativa, a aproximação dos judeus com os grupos socialistas que lutavam por mudar a ordem política da Rússia e do mundo, sinaliza para o fato de que os perseguidos da política opressiva do Czar russo unem forças para se opor a essa opressão. Simpatizando como os dois movimentos, Abramson não se sentia parte de nenhum deles. Hava Blumin diz a Abramson que este deveria escrever seus artigos em russo, a língua da cultura e da grande revolução que se aproximava, a língua na qual havia facilidade para editar e publicar. Porém Abramson mostra-se fiel a seu ideal: tornar o Hebraico numa língua conhecida, elevada e aceita. Ele confronta os incrédulos que não acreditavam na viabilidade do renascimento desta língua. Abramson segue seu caminho e renuncia até a sua paixão pela jovem judia que abraçou a via da luta socialista e preferiu sonhar que seria aceita como igual se somente se transformasse numa jovem russa chamada Yeva Issacovna.

Se ele aceitasse escrever numa língua viva como o russo ou até o iídiche, sua vida seria diferente a tal ponto de poder ter sustento e a mulher a quem admira e ama, mas ele é um idealista convicto apegado ao sonho do renascimento da língua do passado. Assim encontramos esta citação no conto:

\begin{abstract}
Ah, se ele fosse por seu caráter e características um escritor numa língua viva, quão diferente seria a situação, quão completa e feliz seria agora sua vida. Ele que possui tantas qualidades e tanta capacidade para trabalhar e trabalhar e trabalhar. Se assim fosse, ele poderia chegar até os grandes centros literários e poderia ali fundar uma editora própria, nova e de vanguarda ou ainda, poderia se dedicar com todas as suas forças a trabalhar numa das editoras já existentes. Toda sua vida seria absorvida por este árduo trabalho, ele estaria lutando pelo que acredita. $E$ ela? $O$ refinamento dela pela literatura é muito desenvolvido, então ela poderia
\end{abstract}


estar com ele, ao seu lado, sim, ela poderia andar com ele. Ela o incentivaria, o elevaria, faria com que ele sinta com todas as forças o espírito humano que sopra nele, ela supriria seus defeitos complementando-o com sua personalidade e com todos os fundamentos e princípios que ela possui, ela, Hava, uma mulher agradável, uma alma pura. (BRENNER, 1923, p. 52)

Com o passar do tempo, Abramson decepciona-se ao perceber que são poucos, até mesmo entre os jovens, os que se interessam por ler o jornal Hebraico Hashachar (O Amanhecer). No entanto, ele ainda acredita na justeza de sua escolha: "sou hebreu e escrevo em Hebraico para os hebreus" (BRENNER, 1923, p. 37). Ele se afasta dos socialistas e se aproxima dos sionistas ao afirmar: "o que é importante agora para mim é minha nação, com sua libertação eu devo me preocupar e em sua língua nacional eu devo falar, mesmo que a multidão não a domine" (BRENNER, 1923, p. 38). O confronto com Hava Blumin aparece na hora em que a nova Rússia está prestes a surgir. Blumin escolhe o caminho da revolução, pois esta via segundo sua opinião trará alívio à sofrida saga dos judeus. Ela se refere ao sionismo que Abramson abraçou em termos, como uma distante utopia e por isso não se identifica com sua escolha (BRENNER, 1923, p. 39).

Ao longo da narrativa, Abramson se aproxima e simpatiza com os ideias sionistas, mas não abraça o mundo da ação sionista e, aos que o indagam do por que ele não se filia a algum grupo de ação política ligado ao movimento, ele responde num tom incrédulo: "Ashrei hamaaminim" (bem aventurados e felizes os que acreditam) (BRENNER, 1923, p. 41). Quando um dos que o indagavam o vê escrevendo da direita para a esquerda, na língua do passado, ele silenciava e então Abramson era redimido aos olhos do indagador como que imaginando estar vendo a sua frente um sonhador, que em lugar de agir na política dedica sua vida a escrever num código que há tempos está adormecido (BRENNER, 1923, p. 47). Para Abramson, o movimento sionista ainda incipiente não fincou raízes pois ao igual que o socialismo, ele não falava ao coração do povo em nome de Deus e nem lhes prometia pão, ou seja, o sustento 
do dia a dia tão miserável, e nem lhes proporcionava um remédio para a aflição e a insegurança na qual se encontravam no Leste da Europa.

Quando os discursos sionistas e socialistas silenciaram devido ao recrudescimento da opressão política por parte da Rússia do Czar, se tornou preciso voltar à realidade, e diante de tantas carências Abramson é atingido pelo arrependimento. Alguns dos jovens sumiram após insuflar o povo carente com seus discursos e Abramson se questiona como era possível alimentar o espírito se a fome os extinguia ali a todos. A biblioteca sionista da qual Abramson cuidava parou de ser frequentada. Diante de tantas carências, o idealismo de Abramson começou a esvaecer, ele então continuará escrevendo para poucos levando desta forma uma vida de miséria? Para onde esta teimosia o está conduzindo? Um duro golpe o atingiu quando ele recebeu uma carta da redação do jornal Hebraico Hatchyá (O renascimento) na qual os membros da redação declaravam entusiasmo pela capacidade e eloquência do autor neste teor:

Prezado senhor e elevado escritor: ficamos felizes com sua promessa de continuar brindando ao Hatchyá com artigos de sua autoria. Desta forma nos é grato lhe informar que seu artigo intitulado ' $A$ influência do Hassidismo sobre as novas correntes literárias' tem causado forte impressão e que todos lhe vaticinaram um grande futuro no campo da crítica literária. Porém, para nossa tristeza, não temos como atender a seu pedido de um pequeno e antecipado adiantamento monetário. Tanto a redação como o próprio jornal encontram-se numa situação de extrema precariedade. Quando nos enviar seu próximo artigo sobre 'A literatura hebraica nos primórdios do século $\mathrm{XX}$ ', tentaremos lhe enviar alguma quantia em dinheiro antes que o jornal seja impresso. (BRENNER, 1923, p. 52)

Após um intenso confronto interno e diante de tantas adversidades, 
Abramson lançou ao fogo seus escritos em Sfat Avar (a língua do passado), e assim todos os seus ideais são consumidos e queimados. O ensino do Hebraico na cidade $\mathrm{A}$. foi abandonado, o cheder reformado deixou de funcionar. O herói da narrativa decidiu escrever em russo um artigo sobre o nacionalismo europeu e mesmo assim, durante a escrita, ele é dominado pelo sentimento de culpa, ele percebe que seu artigo e ele próprio estão carentes de sentido e de conteúdo. Ele vê com tristeza o aumento no número de jovens judeus mergulhados na cultura russa, ele se sente culpado por ter abandonado seu povo, assim como os outros jovens o abandonaram para abraçar o socialismo e se desligaram de sua própria cultura.

Com a sensação de fracasso e profundamente frustrado, ele decide abandonar A, a grande cidade, e volta cabisbaixo para sua aldeia onde é recebido como um herege que retorna ao lar. $\mathrm{Na}$ aldeia a população judaica foi atingida por boatos que anunciavam a aproximação de um novo pogrom. Desta forma, o distúrbio que se aproxima vai devolver a normalidade ao mundo judaico, nem o sionismo e nem o socialismo serão capazes de impedir a repetição de um novo pogrom. Abramson decide fugir, atormentado por ter virado as costas para o renascimento do Hebraico e por ter traído a causa. No final, o pogrom voltou a atingir a todos, tanto os judeus sionistas como aqueles que simpatizavam e militavam no movimento socialista russo. A realidade crua voltou a se impor, as duas ideologias voltaram para seu antigo lugar, à estante onde se guardavam as utopias judaicas.

Ao voltar para sua aldeia natal, Abramson foi recebido pelo seu pai Reb Itzchak com sua longa e vasta barba que indaga o filho onde teriam ido parar seus filactérios. Ainda o alerta que para encurtar o sofrimento do pai e para ser aceito novamente na aldeia, ele terá que redimir-se com sinceridade, retornar ao caminho certo e lhe diz:

Veja meu filho, que feliz está Shlomo Frankel que também retornou da grande cidade para a casa de seu pai. Porém o grande Rav daqui não te aceitará até que você retorne com convicção, nosso Rav é reverenciado e temido por todos os que o rodeiam e aqueles que lhe servem, fazem tudo o que ele ordena, vão atrás e 
investigam todo membro de Yeshivá que se desviou do caminho certo. Saiba também que o destino do pecador é amargo. Retira, portanto, meu filho os deuses estranhos do teu meio, se desfaz do Hatchyá (o jornal em Língua Hebraica) que está por baixo de suas vestimentas e então viajarei contigo imediatamente até a casa do Rav com o intuito de conseguir seu perdão e a tua admissão na nossa aldeia. (BRENNER, 1923, p. 72)

Se ele se redimir o alerta seu pai, então não voltará a passar fome como na cidade A. onde por causa do capricho de querer ver o mundo novo, acabou se dando mal por uma mera ilusão. Quando Abramson vê a sua frente o grande rabino da aldeia, ele começa a tremer e foge, mas o rabino vai atrás dele e Abramson sente a necessidade de correr pelas montanhas e pelos vales a procura de um lugar no qual ele poderá voltar a ler seu tão amado jornal Hatchyá. Mas o rabino lhe avisa: "Não continua adiante, estou seguindo seus passos, fique parado. Uma grande aldeia há do outro lado do rio, porém lá ninguém entende a sua língua" (BRENNER, 1923, p. 73). Abramson está temeroso, a sua frente estava a aldeia desconhecida e hostil, atrás dele o grande rabino, a sua direita e à esquerda somente montanhas e vales. Ele está prestes a cometer um ato extremo, acabar com sua existência miserável e carente de sentido. Ele retrocede e cai. Ao amanhecer, Abramson acordou e voltou agoniado para a aldeia e foi até a casa de estudos, lugar no qual reflete sobre seu destino e então se vê como um mártir. Uma de suas últimas falas no fim da narrativa: "Ainda não se esvaneceu a esperança de voltar a construir e dar a vida à casa de Israel" (BRENNER, 1923, p. 76). Este é o fim do herói, o fim aparente de uma tentativa de encontrar a redenção.

Itzchak Bacon afirma que o que caracteriza a obra de Brenner entre os anos de 1899 e 1904 é a predominância da figura do herói caracterizado como um jovem solitário e angustiado. Quem criou esta figura foi Berdichevsky do qual Brenner foi admirador e discípulo. Brenner segue o caminho de Berdichevsky que cria o herói que sai a procura de novos ideais, que quer mudar o mundo que o rodeia, mas o choque com a realidade lhe causa profunda frustração 
(BACON, 1978, p. 50). Brenner sinaliza no conto que a velha geração acabou seu papel e que surgiu uma nova geração, e que a realização do sonho pode demorar e a espera é frustrante, porém em nome dessa visão é preciso continuar vivendo. Trágico fim tem o renascimento da língua do passado e Abramson segue esse mesmo fim, mas ele deve seguir vivendo.

Desta forma podemos concluir que a obra de Brenner não se liga a uma ideologia política ou social, não exalta o sionismo e nem anula a vida na diáspora, apenas aponta que esta foi uma experiência negativa, a critica, mas não a condena. Por outro lado, os movimentos sociais são rejeitados por seus heróis. A única coisa que vale a pena para Brenner é o ser humano que cumpre ou que conquista em sua vida ou por intermédio da morte, uma conduta verdadeira de retidão ética.

Para Guershon Shaked, os heróis de Brenner são miseráveis e o mundo que os cerca também o é. Seus heróis peregrinam, se apaixonam, procuram um caminho, fracassam e são destruídos. Seus personagens são fracos de espírito e desta forma, eles acabam se reconciliando com a dura realidade que os rodeia e que uma vez os fez fugir, realidade esta que se mostra pobre e que não pode ser consertada. Seu herói, às vezes, perde a razão, volta para a aldeia natal para se submeter aos desígnios de seu destino, onde será visto como um pecador e como um perdedor, que ousou se desviar do caminho da tradição para ao final ser derrotado. Ou ainda, este acabará deitado à margem das vias do trem ou ainda, se extinguirá à margem da vida esperando a morte chegar, fracassado e abandonado (SHAKED, 1977, p. 377). 


\section{Referências}

BACON, Itzhak. Hatsair haboded bassiporet haivrit - 1899 - 1908. (The Solitary youth in Hebrew fiction 1899 - 1908). Ramat Gan: Publishing House Student's organization, Tel Aviv University, 1978.

BARROCAS, Ester. A Língua Hebraica? Vai bem obrigada, pelo menos por enquanto. Cadernos de Lingua e Literatura Hebraica. n. 5, 2006.

BIALIK, Chaim Nachman. "Igueret al Missaviv Lanekudá" (Uma epistola a respeito do conto Em torno do ponto). In: BACON, Itzchak (org.). Yossef Haim Brenner - Mivchar maamari bikoret al yetsirató hassipurit (Yossef Haim Brenner - seleção de textos críticos sobre sua criação literária). Tel Aviv: Am Oved, 1972.

BRENNER, Yossef Haim. Missaviv Lanekudá. Yiddish: Berlin, Yiddisher Literarisher Ferlag, 1923. Acesso em: 02 jan. 2011. Disponível em: <http://benyehuda.org/brenner/misaviv. html $>$ (Em torno do ponto)

EISENSTADT, Shmuel Noah. Sociedade Israelense. São Paulo: Perspectiva, 1977.

SHAKED, Gershon. Hassiporet haivrit - 1880 - 1970 (Hebrew Narrative Fiction). Tel Aviv: Hakibbutz Hameuchad and Keter, 1977.

SHAPIRA, Anita. Yehudim, tsionim umá shebeneiem (Jews, Zionists and in between). Tel Aviv: Am Oved, 2007. 